\title{
Remote Employment as a Form of Labor Mobility of Today's Youth
}

\author{
Absalyamova S.G. a \\ Absalyamov T.B. ${ }^{b}$ \\ a b Kazan Federal University, Institute of Management, Economics and Finance, Kazan, 420008, Russia \\ Emai: abstimur@yandex.ru
}

\section{Doi:10.5901/mjss.2015.v6n1s3p227}

\begin{abstract}
The article analyzes the current state of the labour market and describes new flexible forms of employment. Also the paper deals with the changes in the nature and content of the labour, which are connected with the transition to a post-industrial society. The article reveals the problems of accounting and evaluation of remote employment and analyzes the positive and negative socio-economic effects of different forms of flexible employment. Particular attention is paid to the study of the remote employment effect on the youth labour mobility.
\end{abstract}

Keywords: non-standard forms of employment, remote work, flexible employment, telework, freelance, downshifting

\section{Introduction}

With the transition to a post-industrial economy, there are dramatic changes in the nature and content of labour and labour relations, which are believed as a "response" to the call of some "revolutions": technological, organizational, motivational, consumer etc.

Nowadays we can see spreading of non-standard forms of employment, decentralization and global changes in the motives of labour behavior. Standardization and unification, which are typical for labour relations in the industrial economy, are being replaced by destandartization of labour in the post-industrial society, fickle hiring, fixed-term contracts and the development of flexible forms of employment become widespread.

The development of information and communication technologies and the Internet has opened a virtual space for work, has formed the Internet economy (e-economy) and the corresponding electronic markets (e-markets, virtual markets) and electronic business (e-business, e-commerce). Information and communication technologies have not only changed the structure of employment, the ratio of working and leisure time, but also opened up new avenues for selfemployment. Modern communications make it possible to realize the intellectual capital, working at any distance from the place where the performance is needed. In this regard, science began to use the terms "remote work", "telework", "telejob".

The growth of non-standard forms of labour is most prevalent mainly in developed countries. In the U.S. they covered one third of workers, in Japan part-time jobs make up one quarter of the total number of jobs.

Remote work for the youth of today is a new form of employment, which has become possible due to the development of telecommunications technology. The youth actively moves to work in the conditions of flexible employment. It happens because of the fact that young people, representing the most mobile socio-demographic group, are characterized by a high degree of susceptibility to a variety of innovations, high level of labour mobility and intellectual activity. Young people have a set of socio-cultural, generational and value features, age characteristics, which distinguish this group from other age groups. Nowadays, Russian youth considers remote employment mostly as an additional type of labour, a form of labour mobility. According to young people's opinions, having the remote socio-labour practice allows a person to choose the type of activity, the organization, the manager or customer, the very place to work. All of this increases its value to young people.

\section{Materials and Methods}

The research was based on the analysis of current trends in the transformation of labor relations, conducted with using of methodological tools of leading scientific schools, as well as the results of empirical studies of flexible employment.

The founders of the scientific concept of remote employment are American scientists Jack Nilles and Francis 
Kinsman.

Jack Nilles in the early 1970s, as the head of the first telecommuting project in the University of Southern California, noticed that in some cases it's easier to deliver work to the man, and not vice versa, and introduced the concept of remote employment, "telework" or "telecommuting" that involve working at a distance, outside the traditional workplace, when the transmission and receipt of information is carried out by using modern telecommunication technologies [6].

One of the most famous and worldwide recognized specialist in the study of remote and virtual office employment is Gil Gordon, editor of one of the best telework magazines "Telecommuting Review", co-author of "Telecommuting: How to Make It Working for You and Your Company" (1986) and «Teleworking Explained "(1993) [3].

Great contribution to the study of "telework" has made the International Labour Organisation (ILO). ILO experts within the concept of "decent work" explored remote employment, changes in the meaningfulness of telework, which allowed Vittorio Di Martino to publish a book "On the way to work at a distance" in 2001 [2].

Since the late 1990s in Western Europe and the United States there have been several large-scale empirical studies on various aspects of the transformation of employment and labour relations.

The most representative studies are:

1. The research of American freelancers (Sologig.com Freelance Survey), conducted in 2007 by market research firm Harris Interactive commissioned by the remote job exchange. Surveyed 2400 companies served by freelancers and 5600 self-employed.

2. The worldwide research of freelancers (Global Freelancer Survey of 2007), United States, FreelanceSwitch. The survey covered 3,700 freelancers of different professions from six continents.

To designate a new category of workers, U.S. researchers T. Malone and R. Laubacher introduced a special term "electronic freelancer" or e-Lancer [5].

Almost all self-employed workers, representing "computer professions" (programmers, web designers), are eLancers. Modern e-Lancers can be called "homeworkers" of the information economy era.

\section{Results}

Not many works are devoted to establishment and development of remote employment in Russia.

There is no holistic understanding of the concept of remote employment among Russian scholars and practitioners. First of all, it is connected with the blurring of the boundaries of the remote employment sphere, and secondly, with the complexity of determining the extent of the phenomenon and the parameter estimates due to the lack of reliable information about it and a significant discrepancy between the results obtained by different valuation methods.

Among Russian studies on remote employment, we should specially mention innovative researches that were carried out with the support of Science Foundation of HSE and, in particular, the work of D.O. Strebkov, A.V.Shevchuk etc. [7].

Analysis of the results of online surveys helped to create the socio-demographic and professional portrait of contemporary Russian freelancer. Freelancers are relatively young: only $3 \%$ of respondents are over 45 years old, fourfifths of respondents (79\%) are older than 30 years, and $59 \%$ are aged $18-26$ years. The average age of the total sample is 27 years.

Most freelancers have recently entered the labor market: $17 \%$ has more than ten years of professional experience, nearly half of respondents (48\%) had less than five years.

Seniority of freelance activity is significantly shorter: $23 \%$ have worked less than a year; $24 \%$ work in the electronic market for 1 year; 30\% - from two to three years; and only 4\% - more than ten years. On average, total seniority of surveyed workers is seven years, and freelance work experience is three years. Most respondents said they did not have day-offs, and their working day on average was much longer than the normal working day of the office worker. Freelancers have a high level of education: $80 \%$ of respondents have higher or incomplete higher education, which is significantly better the average for Russia.

Depending on job searching method, freelancers were divided into three groups. The first group ( $14 \%$ of respondents) uses only market methods such as remote job exchange, websites, forums, social networks. $40 \%$ of respondents use only their social capital (relationships with customers, recommendations from friends, acquaintances and former clients). And $47 \%$ of respondents have the mixed strategy, using the market and social channels to find new customers.

The study allowed us to make a model of a modern freelancer:

$F=f(A, E, I L, A I T)$, where 


\section{F - freelancer;}

A - age;

E - education level;

IL- intellectual work;

AlT - access to information technologies.

The research of freelancers' behavior reveals both positive and negative aspects of telecommuting. The positive aspects are independent organization of the working day, independence in the control of labor and decision-making, obtaining a diverse work experience and working at home. Among the negative aspects there are financial instability, low wages, unstable workload, lack of social guarantees. Freelancers are quite often faced with full or partial non-payment, cancellation of completed order without compensation, etc. One of the ways to solve these problems is the conclusion of an official contract.

Table 1. Positive and negative effects of remote employment

\begin{tabular}{|c|c|c|}
\hline & Positive & Negative \\
\hline For employers & $\begin{array}{l}\text { The use of flexible business processes and flexible staff } \\
\text { Reduced labour costs } \\
\text { Payment for results, not for time worked } \\
\text { Increasing the share of outsourcing }\end{array}$ & $\begin{array}{l}\text { The complexity of checking qualifications } \\
\text { when hiring } \\
\text { The lack of forms of control over the current } \\
\text { production activities of staff } \\
\text { Legal difficulties of the relationship between } \\
\text { teleworkers and employers }\end{array}$ \\
\hline For employees & $\begin{array}{l}\text { The possibility of self-realization } \\
\text { Opportunity to choose the ratio of work and leisure time } \\
\text { The possibility of obtaining additional income } \\
\text { Opportunities for retired persons, for persons with } \\
\text { disabilities, for mothers with little children } \\
\text { Saving the time, that is being wasted when you getting } \\
\text { to your workplace/office }\end{array}$ & $\begin{array}{l}\text { Legal difficulties of the relationship between } \\
\text { teleworkers and employers } \\
\text { Reduction of social guarantees } \\
\text { organization of labour at home is not always } \\
\text { effective } \\
\text { the weakening of the collective values }\end{array}$ \\
\hline $\begin{array}{c}\text { For society as a } \\
\text { whole }\end{array}$ & $\begin{array}{l}\text { Improvement of the quality of life of the population } \\
\text { Reduction of unemployment, the growth of labour } \\
\text { market flexibility } \\
\text { Equal access for all social groups and regions } \\
\text { Improvement of the information society } \\
\text { the solution of transport and ecological problems }\end{array}$ & $\begin{array}{l}\text { Reduction of budget revenues due to the } \\
\text { concealment of the earnings } \\
\text { Increase in the proportion of gray salaries } \\
\text { Reduction of the level of social protection of } \\
\text { citizens } \\
\text { The need to resolve conflicts between } \\
\text { employers and teleworkers }\end{array}$ \\
\hline
\end{tabular}

Interesting research of the problems of flexible employment in Russia is a study conducted in the IV quarter of 2012 by online agency Recruitnet and named "Job 2.0."

According to the results of this study, $64 \%$ of surveyed companies have remotely working employees in their state, and $67 \%$ have a system of flexible employment. Almost all of the respondents plan to continue to use non-standard forms of employment. Study shows, that giving employees the opportunity for flexible schedule is one of the key factors to increase the company's attractiveness as an employer in today's labor market.

The main problems that face companies during the using of remote and flexible employment are unwillingness to effectively manage remote employees (37\%), difficulties of team work (37\%), risks of decreasing of the business security level (32\%), inability to lead the person who is not in the office quickly (26\%).

Also, among the reasons of the low active dissemination of remote and flexible employment at Russian enterprises respondents identify inertia and distrust of management to these forms of organization of the labor process.

On the other hand, there are some possible benefits of using of remote employment and they are all assessed as sufficiently important. First and foremost, it is an opportunity to hire qualified employees regardless of their location, as well as the opportunity to pay for the work results, not for the process.

The results of these two surveys of Russian remote employment (or telework) complement each other, revealing its essential features from the perspective of the employee and the employer. $[10,11]$ :

It is advisable to divide the remote employment is not on a sectoral basis, but on areas of professional activity

With the transition to a post-industrial economy the new trends in the proportion of working and leisure time were discovered. 
Firstly, the very concept of labor has transformed. It is gradually losing its dominant position in the human life. Labor activity is often seen as a mean to maintain a certain standard of living. At the same time, success, selfactualization and other life values are transferred to the sphere of leisure activity.

Secondly, leisure time changes its structure now. It is increasingly associated with the various types of selfrealization and intense intellectual activity. This phenomenon is called "ecological leisure." Today, a certain part of the population begins to refuse the standards of "the good life" and goes to a different value system. In this context, we should mention the book of E. von Weizsäcker "Factor 5", dedicated to finding ways to save modern society from the inevitable self-destruction [8]. Also, the authors explore the conflict between the interests of the sufficiency and employment.

The phenomenon of last years is downshifting - the transition from well-paid, but connected with excessive stress loads and taking all the leisure time job to a more relaxed, although low-paid job. The main symptom of downshifting is the rejection of a career, growing consumption, social status and style of life for the other values in life, especially family, hobbies, healthcare.

Moreover, among the youth of today, it has become fashionable to work outside the office. The number of freelancers is growing; they are people, who enter the labor market as independent service providers using the Internet. Modern communications allow them to realize their intellectual capital, working at any distance from the place where their activities are in demand. In this way, workers can organize the work process and determine the time of work and leisure by themselves. Held in 2008, "The first all-Russian census of freelancers" has created socio-demographic and socioprofessional portrait of the modern freelancer. Two-thirds of them are male, four-fifths (79\%) are under 30 years old, $80 \%$ have higher or incomplete higher education.

One of the main features of the information technology paradigm is flexibility. Moreover, the flexibility applies to both the production system and society in general, and to the organization of work and working time $[1,9]$. Labor activity gradually falls into the spheres of strict regulation and the possible variability.

According to Charles Handy, by bringing in a single portfolio both traditional and flexible forms of employment and forming a "portfolio" of thinking, you can control the flow of funds in different periods of life and various life situations [4]. In this sense, self-employment, part-time work can create a more sustainable and at the same time flexible foundation of material existence.

Overall, the proportion of self-employed in Russia is about 5-6 percent of the working age population - two times less than in developed countries. But it is constantly growing. Non-standard forms of employment restrain fall of living standards and rising unemployment, accelerate the formation of the middle class in Russia, as the middle class uses virtual space to work more actively than other social groups. In addition, non-standard forms of employment play a positive role in expanding of services market, lead to the development of new needs, form new motivations and employment strategies, and also they are an element of the development of innovative economic. Moreover, the spread of flexible employment corresponds to global trends of global labor market.

However, many forms of flexible employment still belong to the informal sector of the economy, which raises a number of serious social problems, and, first of all, leads to loss of a significant part of the state budget funds due to the hiding of income from taxation.

\section{Conclusion}

Thus, the transition to a postindustrial society caused major changes in the nature and substance of labour, labour relations and development of non-traditional forms of employment, strengthened their flexibility, contributed to the emergence of new motivations of labor behavior. New trends in the development of labor relations require further fundamental scientific, economical and practical study.

Due to the fact that many types of flexible employment is not recognized in the official statistics, it is difficult to estimate their scale. As a rule, official statistics don't include freelancers and many other categories of employees, so data for most studies of non-standard forms of employment is collected through online surveys or telephone interviews.

Difficulties of statistical accounting of flexible forms of employment are associated with high heterogeneity of this segment of the labour market. In this case we are not talking about a single socio-economic phenomenon, but a conglomerate of different forms of employment. The boundaries between them are blurred and their status is unsettled. Depending on the choice of criterion, we have a new picture of flexible employment, which is changing with the criterion.

In this regard, one of the primary tasks in the study and statistical account of new, non-traditional forms of employment becomes systematization of flexible forms of work and employment on different criterions that can help to distinguish one type of flexible employment from another and definition of indicators, which can assess the directions of 
flexible forms of employment and the efficiency of its use for employers, employees and society as a whole. In our opinion, the most productive at this stage will be the study of individual segments of flexible employment, whereby it will be possible to allocate unique and typical features of these forms, develop classifications and methods of statistical evidence.

\section{References}

Absalyamova S.G., Yakupova N.M. The research of flexible forms of employment in Russial/ SGEM Conference on Political sciences, Law, Finance, Economics and Tourism 2014. Conference proceedings, volume IV. Albena, Bulgaria, 2014, pp. 783-788.

Nagimova, A.M., Safiullina, F.R. (2014). Combination of university training with employment among Kazan' students. Sotsiologicheskie Issledovaniya, (4), pp. 121-124.

Handy, Ch. The Age of Unreason. London: Business Books, 1989.

Malone, T. The Future of Work: How the New Order of Business Will Shape Your Organization, Your Management Style, and Your Life, Harvard Business School Press 2004.

Melnik, A.N. Problems and prospects of the formation of clusters in the power engineering / A.N. Melnik, A.R. Sadriev // World Applied Sciences Journal. - 2013. - v. 25.

Nilles, J. The Telecommunications-Transportation Tradeoff: Options for Tomorrow, New York: John Wiley and Sons, 1976.

Safina, D., Podgornaya, A. (2014). Mobbing as an organizational phenomenon impeding implementation of changes. Mediterranean Journal of Social Sciences, 5 (18 SPEC. ISSUE), pp. 187-192

Anisimova T.Yu. Analysis of standards in energy management / T.Yu. Anisimova // Middle-East Journal of Scientific Research. - 2013. v. 13 (5). - pp. 654-657.

Strebkov D., Shevchuk A. Freelancers in Russia: Remote Work Patterns and E-Markets, Economic sociology - The European electronic newsletter. Vol. 13. No. 2. pp. 37-45., 2012

von Weizsäcker, E., Hargroves, K., Smith, M., Desha, C. \& Stasinopoulos, P. Factor 5: Transforming the Global Economy through 80\% Increase in Resource Productivity, 2009.

Ajupov A.A. The Design and Use of Swap-Contracts in the Financial Markets // World Applied Sciences Journal, 27(13), 2013, pp. 1-4.

Zhirnova G., Absalyamova S. Global innovation gap and quality of education// 16th International Conference on Interactive Collaborative Learning \& 42nd IGIP International Conference on Engineering Pedagogy, Kazan, Russia, 2013 , pp. 144-145. 